\title{
Association of Parameters of Hospital Admission and the Level of Functional Recovery in Conservatively Treated Patients with Spontaneous Brain Hemorrhage
}

\author{
Srdjan Ljubisavljević1,2, Aleksandra Ignjatović ${ }^{1,3}$ \\ ${ }^{1}$ University of Niš, Faculty of Medicine, Niš, Serbia \\ ${ }^{2}$ Clinic of Neurology, Clinical Center Niš, Niš, Serbia \\ ${ }^{3}$ Public Health Institute Niš, Niš, Serbia
}

SUMMARY

The aim of the paper was to identify the correlation between the parameters of hospital admission and clinical outcome in nontraumatic intracerebral hemorrhage (ICH) patients younger than 65 years, who were not surgically but conservatively treated only.

The analyzed data was collected from the medical records of 341 consecutive patients who suffered a nontraumatic ICH and were conservatively treated. Demographics, medical history, clinical, radiological and biochemical variables on hospital admission and other relevant findings were analyzed in reference to functional outcome of non-traumatic ICH (measured on discharge from hospital).

The following parameters were recognized as the predictors of fatal clinical outcome: lower values of GCS (OR 0.686, $\mathrm{p}=0.023$ ), high values of NIHSS (OR 1.258, $\mathrm{p}<0.001$ ), body temperature on hospital admission (OR $1.896, p=0.034)$, absence of headache in ICH clinical presentation (OR $0.298, p=0.012)$ as well as the sedimentation rate (OR 1.028, $\mathrm{p}=0.045$ ). The predictors of good clinical outcome after ICH were as follows: high values of GCS (OR 1.876, $p=0.032$ ), lower values of NIHSS (OR $0.841, p=0.002)$ and persistence of headache in ICH clinical presentation (OR 5.115, $\mathrm{p}=0.001$ ).

Recognition of predictive factors could help to identify the patients at high risk of ICH progression and can help in the selection of pathogenetic therapy that could minimize the possibility of $\mathrm{ICH}$ progression.

Key words: brain hemorrhage, functional recovery 


\section{INTRODUCTION}

Intracerebral hemorrhage $(\mathrm{ICH})$ is considered as a cerebrovascular event characterized by a high mortality rate, recurrence and permanent disability of the diseased (1). Despite progress in the therapeutic treatment of patients with ischemic stroke and subarachnoid hemorrhage, there is still no fully effective therapy for ICH. It has been shown that the most effective treatment is the one that prevents the progression of $\mathrm{ICH}$ as early as possible. This is important given that $20-30 \%$ of patients show de-terioration within a few hours of the moment of ICH on-set (2).

A number of researches have been done to test the predictors of ICH occurrence and its outcome (3). For the most part those findings can serve for risk stratification of ICH progression. Therefore, the strongest predictive factors for ICH outcome identified as non-modifiable are age, initial hemorrhage volume and correspondding clinical status, while fewer ones point to the significance of the so-called modifying parameters for $\mathrm{ICH}$ course and its progression (4). It would be important to test the prediction of the parameters which could be potentially modifiable in the earliest ICH progression, and which could be quickly determined at the moment of arrival at hospital (e.g. body temperature, mean arterial pressure etc). We believed that detection of those predictive factors could help physicians to identify $\mathrm{ICH}$ patients at high risk of ICH progression, but it could also help in the selection of pathogenic therapy that minimizes the possibility of ICH evolution.

In this study, we identified the factors (measured on admission to hospital) associated with the short-term functional outcome (measured on discharge from hospital) in patients with non-traumatic ICH who were conservatively treated.

\section{PATIENTS AND METHODS}

\section{Study design and data collection}

The study was performed as a retrospective clinical study for which the Ethical approval was not required, and was carried out strictly in accordance with the principles of the Declaration of Helsinki as revised in 2000, ensuring full patient anonymity.

A retrospective review of medical records of patients who suffered a non-traumatic ICH was undertaken. Patients were identified and data were abstracted from our database for the period from January 2013 to June 2017. Clinical data obtained at the time of admission to hospital were collected. Demographics, medical history, clinical, radiological and biochemical variables and other relevant findings were analyzed in reference to functional outcome of $\mathrm{ICH}$.

\section{Study patients}

Data of 341 patients hospitalized with a first-ever non-traumatic ICH were used in this study. Patients were recruited among consecutive patients with acute ICH confirmed by computed tomography (CT) scan. The ICH patients under study met the following criteria: age from 18 to 65 years, absence of head trauma, admission to hospital within $24 \mathrm{~h}$ after the onset of symptoms and having non-traumatic ICH as the final diagnosis on hospital discharge. Patients with ICH resulting from trauma, conversion of an ischemic infarct, carotid or vertebrobasilar dissection, intracranial venous thrombosis, history of acute or chronic infection, malignant diseases and immunosuppressive treatment were excluded. Patients with non-traumatic ICH having incomplete or inconclusive data were excluded $(n=21)$. Therefore, these findings were not analyzed.

\section{Clinical evaluation}

On admission to the Clinic, all the patients underwent routine clinical and neurological examination as well as biochemical and radiological evaluation. All analyses were performed in close temporal relation to the time of the onset of symptoms. The neurological presentation was assessed using the Glasgow Coma Scale (GCS) and National Institutes of Health Stroke Scale (NIHSS). Modified Rankin Scale (mRS) scores on discharge as well as duration of hospitalization were also analyzed. Based on the values of $\mathrm{mRS}$, the included ICH patients were divided in those having good $(\mathrm{mRS}=1-2)$, bad (mRS $=3-5)$ and fatal $(\mathrm{mRS}=6)$ outcome.

Cardiovascular factors were evaluated on admission to the clinic through the assessments of pulse pressure, mean arterial pressure, heart rate, body temperature or the presence of arterial hypertension (defined as $140 \mathrm{mmHg}$ for systolic and/or $90 \mathrm{mmHg}$ for diastolic blood pressure) as well as regularity of antihypertensive therapy use. The presence of diabetes mellitus (the diagnosis was based on the obtained values of $\mathrm{HbA}_{1} \mathrm{C} \geq$ $6.5 \%$ or the values of glucose in the blood $\geq 7.0 \mathrm{mmol} / \mathrm{L}$ after no caloric intake for at least $8 \mathrm{~h}$ ), chronic renal failure, atrial fibrillation, alcohol abuse and other comorbidities in medical history were also analyzed. The main clinical presentation of ICH was estimated 
through the existence of neurological symptoms (cranial nerve impairments, pyramid, sensory or combined injuries), loss of consci-ousness, headache and others. Laboratory tests - glucose values, complete white blood cells (WBCs) count, C reac-tive protein (CRP) and sedimentation rate were deter-mined immediately after admission. In patients recei-ving oral anticoagulant therapy (OAT), hemocoagula-tion analyses were also done.

The presumed etiology of each ICH was determined based on a combination of clinical and radiological data - ICH assigned to arterial hypertension, arteriovenous malformation, cerebral amyloid angiopathy; ICH in patients receiving OAT; ICH caused by OAT or, if assignment to these etiologic categories was not possible, ICH was classified as undetermined.

The study included patients who were managed conservatively. Patients with ICH are usually hospitallized at a stroke unit; in cases of respiratory insufficiency and the need for mechanical ventilation, patients are admitted to the intensive care unit. In selected cases, when neurosurgical treatment is considered, the patient is transferred to a neurosurgical department and those patients were not included in our present investigation. The conservative management of patients was performed in accordance with the guidelines in force in the given year $(5,6)$.

All study patients were categorized according to the gender, age, comorbidities, CT characteristics, frequency distribution on the clinical scales and other relevant data.

\section{Radiological evaluation}

Brain CT (Aquilion 64 Toshiba) scans were performed on admission to hospital. Radiologists who analyzed the images were blinded to other patients' data. Intracerebral hematoma was defined as lobar (ICH L) if it was predominantly localized in the cortical/subcortical white matter, in the basal ganglia (ICH BG), and brainstem (ICH brainstem), with the presence of intraventricular hemorrhage (IVH). In the settings of multiple hematoma localizations, radiological diagnosis was noted as combination. The presence of hematoma mass effect was also determined. The results of cerebral angiography were described in relation to the presence or absence of arteriovenous malformation. During the hospitalization, a control CT scans were also performed according to the assessment of each individual patient.

\section{Statistics}

The data are presented through the mean values and standard deviation, or through the absolute and relative numbers. In the case of normal data distribution, the comparison of continuous variables with respect to the outcome categories was performed using ANOVA, with a post hoc Tukey test. If the distribution of data was not a normal comparison of continuous variables in relation to the outcome categories, it was performed by the Kruskal-Wallis test. A comparison of the categorical variables was done by the Chi-square test. Potential risk factors for fatal and good outcome testing were performed using univariate and multivariate logistic regression. The hypothesis was tested with a significance threshold of $\mathrm{p}<0.05$. Data analysis was performed using software package SPSS 16.0.

\section{RESULTS}

Data of 341 patients, with ICH as the final diagnosis, who completely met inclusion criteria, were analyzed in this study. Although, in terms of age and gender, all subgroups formed on the basis of the final clinical outcome of ICH were uniform (Table 1). The differences were obtained between duration of hospitalizetion, CGS, NIHSS, pulse pressure, body temperature, existence of chronic renal failure, headache, neurological findings and loss of consciousness as well as radiological findings (hematoma in the ventricular system, basal ganglia and the presence of mass effect) and biochemical parameters such as values of glucose, white blood count and sedimentation rate (Table 1). Table 2 presents the association of radiological findings in reference to the final clinical outcome of the study patients.

The predictors of clinical outcome after ICH were as follows: duration of hospitalization, GCS, NIHSS and persistence of headache, loss of consciousness as well as persistence of blood in the ventricular system. The following parameters were recognized as the the predictors of fatal clinical outcome: the values of pulse pressure, body temperature as well as persistence of chronic renal failure, various localizations of hematoma and persistence of aneurysm. Data are given in Table 3. 
Table 1. Demographic, clinical and paraclinical features of ICH patients according to the clinical outcome

\begin{tabular}{|c|c|c|c|c|c|c|c|c|c|}
\hline \multirow{2}{*}{ Parameter } & \multicolumn{2}{|c|}{ Total } & \multicolumn{2}{|c|}{$\begin{array}{c}\text { Fatal } \\
N=158 / 46,3 \%\end{array}$} & \multicolumn{2}{|c|}{$\begin{array}{c}\text { Bad outcome } \\
N=151 / 44,3 \%\end{array}$} & \multicolumn{2}{|c|}{$\begin{array}{c}\text { Good outcome } \\
\mathrm{N}=32 / 9,3 \%\end{array}$} & \multirow{2}{*}{$\mathrm{p}^{1}$} \\
\hline & Coun & $\%$ & Count & $\%$ & Count & $\%$ & Count & $\%$ & \\
\hline \multicolumn{10}{|l|}{ Gender } \\
\hline Male & 235 & 68.9 & 116 & 73.4 & 100 & 66.2 & 19 & 59.4 & 0.188 \\
\hline Female & 106 & 31.1 & 42 & 26.6 & 51 & 33.8 & 13 & 40.6 & \\
\hline Age (years) & \multicolumn{2}{|c|}{$56.21 \pm 7.72$} & \multicolumn{2}{|c|}{$56.72 \pm 7.38$} & \multicolumn{2}{|c|}{$56.05 \pm 7.54$} & \multicolumn{2}{|c|}{$54.47 \pm 9.88$} & $0.305^{2}$ \\
\hline \multicolumn{10}{|l|}{ Clinical data } \\
\hline $\begin{array}{l}\text { Duration of } \\
\text { hospitalization (days) }^{+}\end{array}$ & \multicolumn{2}{|c|}{$7.74 \pm 5.62$} & \multicolumn{2}{|c|}{$3.51 \pm 3.62$} & \multicolumn{2}{|c|}{$11.43 \pm 4.28$} & \multicolumn{2}{|c|}{$11.25 \pm 4.60$} & $<0.001^{2}$ \\
\hline $\mathrm{GCS}^{+}$ & \multirow{2}{*}{\multicolumn{2}{|c|}{$\begin{array}{l}10.35 \pm 2.15 \\
21.13+6.02\end{array}$}} & \multicolumn{2}{|c|}{$8.89 \pm 2.14$} & \multicolumn{2}{|c|}{$11.50 \pm 1.12$} & \multicolumn{2}{|c|}{$12.19 \pm 0.64$} & $<0.001^{2}$ \\
\hline NIHSS $^{+}$ & & & \multicolumn{2}{|c|}{$25.13 \pm 5.14$} & \multicolumn{2}{|c|}{$18.17 \pm 4.19$} & \multicolumn{2}{|c|}{$15.38 \pm 4.41$} & $<0.001^{3}$ \\
\hline $\begin{array}{l}\text { Pulse pressure } \\
(\mathrm{mmHg})^{\dagger}\end{array}$ & \multicolumn{2}{|c|}{$70.68 \pm 23.66$} & \multicolumn{2}{|c|}{$74.39 \pm 25.98$} & $68.31 \pm$ & 20.43 & $63.59 \pm$ & 23.49 & $0.032^{3}$ \\
\hline $\begin{array}{l}\text { Mean arterial pressure } \\
(\mathrm{mmHg})^{+}\end{array}$ & \multicolumn{2}{|c|}{$121.17 \pm 24.60$} & 123.13 & $=25.44$ & $120.03 \pm$ & 23.50 & $116.88=$ & 25.33 & $0.311^{3}$ \\
\hline Heart rate $(\mathrm{N} / \mathrm{min})^{\dagger}$ & 81.09 & 13.85 & $81.80 \pm$ & 17.06 & $80.48 \pm$ & 10.50 & $80.41=$ & 9.51 & $0.701^{3}$ \\
\hline Body temperature $\left({ }^{\circ} \mathrm{C}\right)^{+}$ & 37.72 & 0.70 & 37.92 & $=0.75$ & $37.56 \pm$ & 0.62 & $37.50=$ & 0.51 & $<0.001^{2}$ \\
\hline Arterial hypertension & 287 & 84,2 & 132 & 83.5 & 126 & 83.4 & 29 & 90.6 & 0.536 \\
\hline Diabetes mellitus & 46 & 13.5 & 19 & 12.0 & 21 & 13.9 & 6 & 18.8 & 0.603 \\
\hline Chronic renal failure & 31 & 9.1 & 21 & 13.3 & 9 & 6.0 & 1 & 3.1 & 0.033 \\
\hline Atrial fibrillation & 8 & 2.3 & 3 & 1.9 & 3 & 2.0 & 2 & 6.2 & 0.426 \\
\hline Alcohol abuse & 31 & 9.1 & 18 & 11.4 & 12 & 7.9 & 1 & 3.1 & 0.223 \\
\hline $\begin{array}{l}\text { Daily use of } \\
\text { antihypertensive Th }\end{array}$ & 160 & 46.9 & 74 & 46.8 & 69 & 45.7 & 17 & 53.1 & 0.746 \\
\hline $\begin{array}{l}\text { Body mass index } \\
\left(\mathrm{kg} / \mathrm{m}^{2}\right)>30\end{array}$ & 61 & 17.9 & 25 & 15.8 & 31 & 20.5 & 5 & 15.6 & 0.527 \\
\hline Headache & 87 & 25.5 & 29 & 18.4 & 40 & 26.5 & 18 & 56.2 & $<0.001$ \\
\hline $\begin{array}{l}\text { Neurological } \\
\text { symptoms }\end{array}$ & 206 & 60.4 & 57 & 36.1 & 123 & 81.5 & 26 & 81.2 & $<0.001$ \\
\hline Loss of consciousness & 137 & 40.2 & 108 & 68.4 & 28 & 18.5 & 1 & 3.1 & $<0.001$ \\
\hline Radiological diagnosis & emorrl & ge loc & lization) & & & & & & \\
\hline IVH & 122 & 35.8 & 78 & 49.4 & 38 & 25.2 & 6 & 18.8 & $<0.001$ \\
\hline SAH & 20 & 5.9 & 12 & 7.6 & 7 & 4.6 & 1 & 3.1 & 0.417 \\
\hline ICH-BG & 120 & 35.2 & 48 & 30.4 & 64 & 42.4 & 8 & 25.0 & 0.038 \\
\hline ICH-LH & 176 & 51.6 & 89 & 56.3 & 71 & 47.0 & 16 & 50.0 & 0.257 \\
\hline ICH-BS & 39 & 11.4 & 19 & 12.0 & 15 & 9.9 & 5 & 15.6 & 0.635 \\
\hline Mass effect & 161 & 47.2 & 98 & 62.0 & 55 & 36.4 & 8 & 25.0 & $<0.001$ \\
\hline Aneurysm & 27 & 7.9 & 7 & 4.4 & 17 & 11.3 & 3 & 9.4 & 0.072 \\
\hline Biochemical data & & & & & & & & & \\
\hline Glycemia $(\mathrm{mmol} / \mathrm{l})^{\dagger}$ & 9.27 & 3.99 & 10.51 & $=4.37$ & $8.14 \pm$ & 3.22 & $8.47 \pm$ & 3.64 & $<0.001^{3}$ \\
\hline WBCs $\left(\times 10^{9} / 1\right)^{\dagger}$ & 12.72 & 8.55 & $14.99 \pm$ & 10.52 & $10.72 \pm$ & 6.19 & $10.94=$ & 2.69 & $<0.001^{3}$ \\
\hline $\mathrm{CRP}\left(\mathrm{mg} / \mathrm{l}^{\dagger}\right.$ & 15.70 & 28.94 & $21.59 \pm$ & 37.74 & $10.84 \pm$ & 17.85 & $9.53 \pm$ & 0.06 & $0.121^{3}$ \\
\hline $\begin{array}{l}\text { Sedimentation rate } \\
(\mathrm{N} / \mathrm{h})^{+}\end{array}$ & 15.80 & 15.84 & $19.45 \pm$ & 19.66 & $12.80 \pm$ & 10.60 & $11.91 \pm$ & 11.02 & $0.006^{3}$ \\
\hline
\end{tabular}

${ }^{+}$Mean \pm SD, ${ }^{1}$ Chi-squared test, ${ }^{2}$ ANOVA, ${ }^{3}$ Kruskal-Wallis test 
Based on the values of mRS ICH patients were divided in those having good (mRS =1-2), bad ( $m R S=3-5)$ and fatal $(\mathrm{mRS}=6)$ outcome; GCS - Glasgow Coma Scale; NIHSS - National Institutes of Health Stroke Scale;

WBCs white blood cells; $\mathrm{CRP}-\mathrm{C}$ reactive protein; $\mathrm{SAH}$ - subarachnoid hemorrhage, $\mathrm{ICH}$ - intracerebral hemorrhage, ICH-LH - lobar localization, ICH BS - brain stem localization, IVH - intraventricular hemorrhage

Table 2. Radilogical diagnosis (hemorrhage localization and presence of its mass effects) of ICH patients according to the clinical outcome

\begin{tabular}{|c|c|c|c|c|c|c|c|c|c|c|}
\hline \multirow{2}{*}{\multicolumn{2}{|c|}{$\begin{array}{c}\text { Radiological diagnosis } \\
\text { (hemorrhage localization and mass } \\
\text { effect) }\end{array}$}} & \multicolumn{2}{|c|}{ Total } & \multicolumn{2}{|c|}{ Fatal } & \multicolumn{2}{|c|}{ Bad outcome } & \multicolumn{2}{|c|}{$\begin{array}{c}\text { Good } \\
\text { outcome }\end{array}$} & \multirow[t]{2}{*}{$\mathrm{p}^{1}$} \\
\hline & & Count & $\%$ & Count & $\%$ & Count & $\%$ & Count & $\%$ & \\
\hline \multirow{2}{*}{ SAH } & without mass effect & 18 & 5.3 & 10 & 6.3 & 7 & 4.6 & 1 & 3.1 & 0.669 \\
\hline & with mass effect & 2 & 0.6 & 2 & 1.3 & 0 & 0.0 & 0 & 0.0 & 0.213 \\
\hline \multirow{2}{*}{ ICH-BG } & without mass effect & 67 & 19.6 & 18 & 11.4 & 43 & 28.5 & 6 & 18.8 & 0.001 \\
\hline & with mass effect & 53 & 15.5 & 30 & 19.0 & 21 & 13.9 & 2 & 6.2 & 0.117 \\
\hline \multirow{2}{*}{ ICH-LH } & without mass effect & 82 & 24.0 & 28 & 17.7 & 42 & 27.8 & 12 & 37.5 & 0.021 \\
\hline & with mass effect & 94 & 27.6 & 61 & 38.6 & 29 & 19.2 & 4 & 12.5 & $<0.001$ \\
\hline \multirow{2}{*}{ ICH -BS } & without mass effect & 26 & 7.6 & 14 & 8.9 & 9 & 6.0 & 3 & 9.4 & 0.578 \\
\hline & with mass effect & 13 & 3.8 & 5 & 3.2 & 6 & 4.0 & 2 & 6.2 & 0.726 \\
\hline \multirow{2}{*}{ IVH } & without mass effect & 67 & 19.6 & 36 & 22.8 & 26 & 17.2 & 5 & 15.6 & 0.391 \\
\hline & with mass effect & 55 & 16.1 & 42 & 26.6 & 12 & 7.9 & 1 & 3.1 & $<0.001$ \\
\hline \multirow{2}{*}{ Combination } & without mass effect & 73 & 21.4 & 40 & 25.3 & 30 & 19.9 & 3 & 9.4 & 0.086 \\
\hline & with mass effect & 53 & 15.5 & 39 & 24.7 & 13 & 8.6 & 1 & 3.1 & $<0.001$ \\
\hline
\end{tabular}

${ }^{1}$ Chi-squared test

215 of ICH patients had only one radiological diagnosis (localization of hemorrhage), 126 of ICH patients had two or more localizations (combination)

SAH - subarachnoid hemorrhage, ICH - intracerebral hemorrhage, ICH-LH - lobar localization, ICH BS - brain stem localization, IVH - intraventricular hemorrhage

Table 3. The influence of demograhic, clinical and paraclinical features of ICH patients on clinical outcome (univariate logistic regression analysis)

\begin{tabular}{|c|c|c|c|c|c|c|}
\hline \multirow{2}{*}{ Parameter } & \multicolumn{3}{|c|}{ Fatal outcome } & \multicolumn{3}{|c|}{ Good outcome } \\
\hline & OR & $95 \% \mathrm{CI}$ & $\mathrm{p}$ & OR & $95 \% \mathrm{CI}$ & $\mathrm{p}$ \\
\hline Gender & 0.673 & $0.423-1.073$ & 0.096 & 1.589 & $0.754-3.351$ & 0.224 \\
\hline Age & 1.016 & $0.988-1.045$ & 0.260 & 0.972 & $0.932-1.013$ & 0.182 \\
\hline \multicolumn{7}{|l|}{ Clinical data } \\
\hline Duration of hospitalization (days) & 0.647 & $0.597-0.703$ & $<0.001$ & 1.125 & $1.054-1.200$ & $<0.001$ \\
\hline GCS & 0.369 & $0.298-0.455$ & $<0.001$ & 3.211 & $1.889-5.457$ & $<0.001$ \\
\hline NIHSS & 1.391 & $1.295-1.494$ & $<0.001$ & 0.804 & $0.741-0.873$ & $<0.001$ \\
\hline Pulse pressure (mmHg) & 1.013 & $1.003-1.022$ & 0.008 & 0.985 & $0.968-1.002$ & 0.076 \\
\hline Mean arterial pressure $(\mathrm{mmHg})$ & 1.006 & 0.997-1.015 & 0.173 & 0.992 & 0.976-1.007 & 0.299 \\
\hline Heart rate (N/min) & 1.007 & $0.992-1.023$ & 0.378 & 0.996 & $0.969-1.023$ & 0.770 \\
\hline Body temperature $\left({ }^{\circ} \mathrm{C}\right)$ & 2.245 & $1.618-3.114$ & $<0.001$ & 0.578 & $0.324-1.030$ & 0.063 \\
\hline
\end{tabular}




\begin{tabular}{|c|c|c|c|c|c|c|c|}
\hline \multicolumn{2}{|c|}{ Arterial hypertension } & 0.917 & $0.512-1.641$ & 0.771 & 1.911 & $0.561-6.512$ & 0.301 \\
\hline \multicolumn{2}{|c|}{ Diabetes mellitus } & 0.790 & $0.421-1.483$ & 0.463 & 1.552 & $0.602-4.004$ & 0.363 \\
\hline \multicolumn{2}{|c|}{ Chronic renal failure } & 2.652 & $1.209-5.818$ & 0.015 & 0.300 & $0.040-2.277$ & 0.244 \\
\hline \multicolumn{2}{|c|}{ Atrial fibrillation } & 1.681 & $0.796-3.551$ & 0.173 & 0.300 & $0.014-2.772$ & 0.247 \\
\hline \multicolumn{2}{|c|}{ Alcohol abuse } & 0.689 & $0.162-2.930$ & 0.614 & 3.367 & $0.651-17.420$ & 0.148 \\
\hline \multicolumn{2}{|c|}{ Daily use of antihypertensive Th } & 0.994 & $0.649-1.522$ & 0.977 & 1.316 & $0.634-2.728$ & 0.461 \\
\hline \multicolumn{2}{|c|}{ Body mass index $\left(\mathrm{kg} / \mathrm{m}^{2}\right)>30$} & 0.768 & $0.438-1.346$ & 0.356 & 0.837 & $0.309-2.268$ & 0.726 \\
\hline \multicolumn{2}{|c|}{ Headache } & 0.484 & $0.291-0.806$ & 0.005 & 4.472 & 2.117-9.448 & $<0.001$ \\
\hline \multicolumn{2}{|c|}{ Neurological symptoms } & 0.129 & $0.079-0.211$ & $<0.001$ & 3.106 & $1.243-7.762$ & 0.015 \\
\hline \multicolumn{2}{|c|}{ Loss of consciousness } & 11.470 & $6.823-19.282$ & $<0.001$ & 0.041 & $0.006-0.304$ & 0.002 \\
\hline \multicolumn{8}{|c|}{ Radiological diagnosis } \\
\hline \multirow[t]{3}{*}{ SAH } & total & 1.798 & $0.716-4.517$ & 0.212 & 0.492 & $0.064-3.804$ & 0.497 \\
\hline & without mass effect & 1.478 & $0.569-3.841$ & 0.423 & 0.554 & $0.071-4.036$ & 0.572 \\
\hline & with mass effect & - & - & - & 0.000 & $0.000-1.005$ & 0.999 \\
\hline \multirow[t]{3}{*}{ ICH-BG } & total & 0.673 & $0.429-1.056$ & 0.085 & 0.586 & $0.255-1.349$ & 0.209 \\
\hline & without mass effect & 0.352 & $0.195-0.634$ & 0.001 & 0.938 & $0.370-2.380$ & 0.893 \\
\hline & with mass effect & 1.630 & $0.903-2.944$ & 0.105 & 0.337 & $0.078-1.456$ & 0.145 \\
\hline \multirow[t]{3}{*}{ ICH-LH } & total & 1.423 & $0.928-2.183$ & 0.106 & 0.931 & $0.450-1.929$ & 0.848 \\
\hline & without mass effect & 0.515 & $0.307-0.863$ & 0.012 & 2.049 & $0.955-4.396$ & 0.066 \\
\hline & with mass effect & 2.858 & $1.743-4.687$ & $<0.001$ & 0.348 & $0.119-1.020$ & 0.054 \\
\hline \multirow[t]{3}{*}{ ICH-BS } & total & 1.114 & $0.572-2.171$ & 0.751 & 1.498 & $0.541-4.148$ & 0.437 \\
\hline & without mass effect & 1.385 & $0.621-3.090$ & 0.426 & 1.286 & $0.364-4.545$ & 0.696 \\
\hline & with mass effect & 0.715 & $0.229-2.231$ & 0.563 & 1.806 & $0.382-8.532$ & 0.456 \\
\hline \multirow[t]{3}{*}{ IVH } & total & 3.080 & $1.943-4.882$ & $<0.001$ & 0.384 & $0.153-0.961$ & 0.041 \\
\hline & without mass effect & 1.447 & $0.846-2.473$ & 0.177 & 0.738 & $0.273-1.993$ & 0.549 \\
\hline & with mass effect & 4.735 & $2.434-9.210$ & $<0.001$ & 0.152 & $0.020-1.140$ & 0.067 \\
\hline \multirow[t]{3}{*}{ Combination } & total & 1.541 & $0.916-2.952$ & 0.103 & 0.353 & $0.104-1.194$ & 0.094 \\
\hline & without mass effect & 1.785 & $0.950-3.117$ & 0.121 & 0.452 & $0.325-1.554$ & 0.088 \\
\hline & with mass effect & 3.956 & $2.057-7.610$ & $<0.001$ & 0.159 & $0.021-1.194$ & 0.074 \\
\hline Aneurysm & & 0.378 & $0.155-0.919$ & 0.032 & 1.228 & $0.349-4.329$ & 0.749 \\
\hline
\end{tabular}

\begin{tabular}{lllllll}
\hline Biochemical data & & & & & & \\
Glycaemia (mmol/1) & 1.185 & $1.107-1.267$ & $<0.001$ & 0.935 & $0.838-1.044$ & 0.234 \\
${\text { WBCs }(x 109 / 1)^{+}}^{+}$ & 1.141 & $1.084-1.202$ & $<0.001$ & 0.942 & $0.865-1.025$ & 0.162 \\
CRP (mg/l) & 1.016 & $1.006-1.027$ & 0.001 & 0.985 & $0.962-1.009$ & 0.226 \\
Sedimentation rate (N/h) $^{+}$ & 1.031 & $1.014-1.047$ & $<0.001$ & 0.976 & $0.944-1.009$ & 0.150 \\
\hline \hline
\end{tabular}

${ }^{+}$Mean \pm SD, OR - odds ratio, 95\%CI - confidence interval

Based on the values of mRS ICH patients were divided in those having good (mRS =1-2), bad ( $m R S=3-5)$ and fatal $(\mathrm{mRS}=6)$ outcome; GCS - Glasgow Coma Scale; NIHSS - National Institutes of Health Stroke Scale;

WBCs white blood cells; $\mathrm{CRP}-\mathrm{C}$ reactive protein; $\mathrm{SAH}$ - subarachnoid hemorrhage, $\mathrm{ICH}$ - intracerebral hemorrhage, ICH-LH - lobar localization, ICH BS - brain stem localization, IVH - intraventricular hemorrhage total - all ICH patients having a radiological diagnosis - 215 of ICH patients had only one radiological diagnosis (localization of hemorrhage), 126 of ICH patients had two or more localization (combination)

Using multiple regression analysis (adjusted for parameters significant in the univariate regression analysis) (Table 4), the following parameters were recogni- zed as the predictors of fatal clinical outcome; lower values of GCS (OR 0.686, p = 0.023), high values of NIH-SS (OR 1.258, $\mathrm{p}<0.001$ ), body temperature on hospital 
admission (OR 1.896, $\mathrm{p}=0.034)$, absence of head- ache in the ICH presentation (OR 0.298, p = 0.012) as well as the sedimentation rate (OR 1.028, $\mathrm{p}=0.045)$. The following values were recognized as the significant predictors of good clinical outcome after ICH: high values of GCS
(OR 1.876, $\mathrm{p}=0.032$ ), lower values of NIHSS (OR 0.841, $\mathrm{p}$ $=0.002)$ as well as the persistence of headache in $\mathrm{ICH}$ presentation (OR 5.115, $\mathrm{p}=0.001)$ (Table 4).

Table 4. The influence of demograhic, clinical and paraclinical features of ICH patients on clinical outcome (multiple logistic regression analysis)

\begin{tabular}{lccc}
\hline \multicolumn{1}{c}{ Risk factors } & OR & $\mathbf{9 5 \%}$ CI & p \\
\hline \multicolumn{3}{c}{ Fatal outcome } \\
GCS & 0.686 & $0.495-0.950$ & $\mathbf{0 . 0 2 3}$ \\
NIHSS & 1.258 & $1.131-1.400$ & $\mathbf{0 . 0 0 0}$ \\
Body temperature & 1.896 & $1.051-3.419$ & $\mathbf{0 . 0 3 4}$ \\
Headache & 0.298 & $0.115-0.770$ & $\mathbf{0 . 0 1 2}$ \\
Sedimentation rate & 1.028 & $1.001-1.056$ & $\mathbf{0 . 0 4 5}$
\end{tabular}

Hosmer-Lemeshow test $\mathrm{p}=\mathbf{0 . 2 4 8}$

\begin{tabular}{lccc} 
GCS & 1.876 & $1.057-3.331$ & $\mathbf{0 . 0 3 2}$ \\
NIHSS & 0.841 & $0.754-0.937$ & $\mathbf{0 . 0 0 2}$ \\
Headache & 5.115 & $2.003-13.066$ & $\mathbf{0 . 0 0 1}$ \\
& Hosmer-Lemeshow test $\mathbf{p}=\mathbf{0 . 6 2 5}$ & \\
\hline \hline
\end{tabular}

OR - odds ratio, 95\%CI - confidence interval

*Adjusted for parameters significant in univariate logistic regression (Table 3)

GCS - Glasgow Coma Scale; NIHSS - National Institutes of Health Stroke Scale

\section{DISCUSSION}

This study confirms that the bad or fatal outcomes are more common phenomena in ICH. Early deterioration even in the first few hours after $\mathrm{ICH}$ onset was recognized as the most significant factor here (1). That is why the rapid diagnostic and attentive management is the basic principle of protocol for clinical care of patients with $\mathrm{ICH}$ (7). The obtained results indicate that CGS, NIHSS and initial clinical presentation of ICH (in terms of the presense or absence of headache, different neurological symptoms, loss of consciousness) as well as persistence of blood in the ventricular system are significant and directly influence the mortality and the level of short-term functional recovery after ICH (Table 1). There are similar results obtained from a much smaller series of ICH patients which also point to high NIHSS score, intraventricular presence of hemorrhage and hematoma extension as independent predictors of $\mathrm{ICH}$ mortality (3). As significant predictors of fatal outcomes we identified the localization of hematoma in the region of the brain stem as well as the compressive effects of hematoma. The presence of hematoma in the region of basal ganglia or subcortical regions but without significant compressive effects is inversely associated with the fatal outcome in $\mathrm{ICH}$. In the settings of hematoma localizations, ICH is mostly presented with headache and neurological symptoms (due to damages to the main central nerve system pathways but also due to the acquisition of the pain matrix). This ICH clinical presentation is recognized as a negative predictor of fatal clinical outcome (Table 3). It has been shown that the distribution of the initial bleeding on hospital admission is the most important factor in predicting the early clinical outcome (8). There are results which suggest the relative significance of the size of the hematoma itself despite the greater significance of its compression on the surrounding tissue. The mass effect as the consequence of the hema- 
toma expansion has been recognized as a pivotal factor in the direct neurological deterioration after ICH (1), as a routine marker of ICH clinical severity as well as a reliable prognostic indicator (9). There are results from respectable series of ICH patients (594 patients) which revealed that the in-hospital mortality rate was significantly associated with cerebral edema, patient's older age (above 80 years) and unconsciousness on admission. The same association between the aforementioned parameters and long-term functional outcome after ICH was also observed (10). The results of the present study support some previous results because the loss of consciousness in the initial ICH presentation is far more commonly associated with a worse ICH outcome. Consideration of other results obtained in this study, wherein hematoma in the region of brain stem (mainly associated with the loss of consciousness in the clinical presentation) is closely accompanied with fatal outcome after $\mathrm{ICH}$, additionally suggests that unconsciousness at $\mathrm{ICH}$ onset can be taken as a relevant clinical predictor of ICH progression. Although our results are almost similar to the previous ones (10), we have not found the impact of patients' age on the ICH outcome which could be the consequence of the inclusion criteria of this study according to which only patients under 65 years were involved, thus excluding the older ones (see section Methodology).

In more than a fifth of ICH patients, clinical presentation worsens even between the prehospital emergency medical service assessment and the initial evaluation in the emergency department, while one fifth of patients demonstrate continuous deterioration within the first hours after arrival to hospital (11). Identification of the so-called modifiable risk factors of ICH clinical deterio-ration and short-term functional recovery is important for the recognition of modifying and individually tailored pathogenetic therapy. In that sense, we found that the basic level of pulse pressure and body temperature positively predict the fatal clinical outcome after $\mathrm{ICH}$, which is similar to the results obtained by other authors (3). It has been found that treatable factors such as blood pressure and body temperature could contribute to the prevention of hematoma growth and reduction of brain edema evolution, thus preventing the clinical deterioration of ICH (12). Higher mortality rates in ICH patient with high level of pulse pressure point to a possible impact of values of blood pressure on hospital admission. There are results which demonstrated that $\mathrm{mRS}$ indicates improved functional outcomes with intensive lowering of blood pressure in ICH patients (11), while there are also results which suggest that lower death rate or disability were not significant comparing ICH patients with aggressive and standard reduction of blood pressure (13). As we presented here, high blood glucose on admission predicts an increased risk of mortality and poor outcome in patients with $\mathrm{ICH}$, independent of the presence of diabetes mellitus (1, 14-16). As we also found, fever is common in $\mathrm{ICH}$ presentation especially after ICH onset in patients with intraventricular hemorrhage and may also be associated with hematoma growth and fatal clinical outcome $(17,18)$. Thus, there are studies which suggest that therapeutic cooling may reduce perihematomal edema thus preventing ICH deterioration $(19,20)$. Regardless of the fact that the patient's medical comorbidities play an important role in ICH pathogenesis (21), we have shown that only chronic renal failure influences the fatal outcome after ICH. Interestingly, there were no similar findings in reference to previous arterial hypertension and other comorbidities and functional recovery after ICH, as demonstrated previously (8). Opposite to our results which suggest a slightly positive prediction of leukocyte count recorded on admission in worse short-term recovery after $\mathrm{ICH}$, there are results that white blood cells on admission were independently associated with good or moderate functional outcome but in long-term functionnal recovery (after one year) (22). Although there was no association between ICH etiology and its mortality or functional outcome in some previous researches (22), we found the negative prediction of the presence of brain aneurisms and fatal clinical outcome of ICH.

Although the motive of the research was identify the modifiable factors for the earliest deterioration of ICH and its clinical outcome, results of the present study mostly confirm the predictive nature of those factors that can only potentially be considered as modifiable.

\section{CONCLUSION}

In conclusion, the prominent predictors of shortterm fatal clinical outcome after ICH are: lower values of GCS, high values of NIHSS, body temperature on hospital admissions, absence of headache in the ICH presentation as well as the increased level of sedimentation rate. On the other hand, the significant predictors of good clinical outcome after ICH were high values of GCS, lower values of NIHSS as well as persistence of headache in ICH presentation. Prospective studies are necessary. 


\section{Conflict of interest}

The authors declare that there is no conflict of interest regarding the publication of this article. 


\section{References}

1. Sun W, Pan W, Kranz PG, et al. L. Predictors of Late Neurological Deterioration After Spontaneous Intracerebral Hemorrhage. Neurocrit Care 2013; 19: 299305.

https://doi.org/10.1007/s12028-013-9894-2

2. Fan JS, Huang HH, Chen YC, et al. Emergency department neurologic deterioration in patients with spontaneous intracerebral hemorrhage: incidence, predictors, and prognostic significance. Acad Emerg Med 2012; 19: 133-8.

https://doi.org/10.1111/j.1553-2712.2011.01285.x

3. Cheung RTF, Zou LY. Use of the Original, Modified, or New Intracerebral Hemorrhage Score to Predict Mortality and Morbidity After Intracerebral Hemorrhage. Stroke 2003; 34: 1717-22.

https://doi.org/10.1161/01.STR.0000078657.22835.B9

4. Brott T, Broderick J, Kothari R, et al. Early hemorrhage growth in patients with intracerebral hemorrhage. Stroke 1997; 28: 1-5.

https://doi.org/10.1161/01.STR.28.1.1

5. Steiner T, Salman RAS, Beer R, et al. European Stroke Organisation (ESO) guidelines for the management of spontaneous intracerebral hemorrhage Int J Stroke 2014; 9(7): 840-55.

https://doi.org/10.1111/ijs.12309

6. Morgenstern LB, Hemphill JC, Anderson C, et al. Guidelines for the Management of Spontaneous Intracerebral Hemorrhage: A Guideline for Healthcare Professionals From the American Heart Association/American Stroke Association. Stroke 2010; 41(9): 2108-29.

https://doi.org/10.1161/STR.0b013e3181ec611b

7. Anderson CS, Becker K, Bendok BR, et al., on behalf of the American Heart AssociationStroke Council, Council on Cardiovascular and Stroke Nursing, and Council on Clinical Cardiology Guidelines for the Management of Spontaneous Intracerebral Hemorrhage A Guideline for Healthcare Professionals From the American Heart Association/American Stroke Association Stroke. 2015; 46: 000-000. https://doi.org/10.1161/STR.0000000000000069
8. Specogna AV, Turin TC, Patten SB, Hill MD. Factors Associated with Early Deterioration after Spontaneous Intracerebral Hemorrhage: A Systematic Review and Meta-Analysis. PLoS ONE 2014; 9(5): e96743.

https://doi.org/10.1371/journal.pone.0096743

9. Appelboom G, Bruce SS, Hickman ZL, et al. Volume-dependent effect of perihaematomal oedema on outcome for spontaneous intracerebral haemorrhages J Neurol Neurosurg Psychiatry 2013; 84: 488-93. https://doi.org/10.1136/jnnp-2012-303160

10. Al-Khaled M, Eggers J, the QugSS2 Study. Prognosis of Intracerebral Hemorrhage after Conservative Treatment. JStroke Cerebrovasc 2014; 23: 230-4. https://doi.org/10.1016/j.jstrokecerebrovasdis.2012.12 .018

11. Anderson CS, Heeley E, Huang Y, et al., for the INTERACT2 Investigators. Rapid Blood-Pressure Lowering in Patients with Acute Intracerebral Hemorrhage. N Engl J Med 2013; 368: 2355-65.

https://doi.org/10.1056/NEJMoa1214609

12. Kuramatsu JB, Huttner HB, Schwab S. Advances in the management of intracerebral hemorrhage. J Neural Transm 2013; 120: S35-S41. https://doi.org/10.1007/s00702-013-1040-y

13. Qureshi AI, Palesch YY, Barsan WG, et al., for the ATACH-2 Trial Investigators and the Neurological Emergency Treatment Trials Network Intensive Blood Pressure Lowering in Patients with Acute Cerebral Hemorrhage N Engl J Med 2016; 375:1033-43. https://doi.org/10.1056/NEJMoa1603460

14. Passero S, Ciacci G, Ulivelli M. The influence of diabetes and hyperglycemia on clinical course after intracerebral hemorrhage. Neurology 2003; 61: 13516.

https://doi.org/10.1212/01.WNL.0000094326.30791.2 $\underline{\mathrm{D}}$

15. Stead LG, Gilmore RM, Bellolio MF, et al. Hyperglycemia as an independent predictorof worse 
outcome in non-diabetic patients presenting with acute ischemic stroke. Neurocrit Care 2009;10:181-6. https://doi.org/10.1007/s12028-008-9080-0

16. Finfer S, Chittock DR, Su SY, et al; NICE-SUGAR Study Investigators. Intensiveversus conventional glucose control in critically ill patients. N Engl J Med 2009; 360: 1283-97.

https://doi.org/10.1056/NEJMoa0810625

17. Schwarz S, Häfner K, Aschoff A, Schwab S. Incidence and prognostic significance of fever following intracerebral hemorrhage. Neurology 2000; 54: 35461.

https://doi.org/10.1212/WNL.54.2.354

18. Rincon F, Lyden P, Mayer SA. Relationship between temperature, hematoma growth, and functional outcome after intracerebral hemorrhage. Neurocrit Care 2013; 18: 45-53.

https://doi.org/10.1007/s12028-012-9779-9
19. Fingas M, Penner M, Silasi G, Colbourne F. Treatment of intracerebral hemorrhage in rats with $12 \mathrm{~h}, 3$ days and 6 days of selective brain hypothermia. Exp Neurol 2009; 219:156-62.

https://doi.org/10.1016/j.expneurol.2009.05.007

20. Kollmar R, Staykov D, Dörfler A, et al. Hypothermia reduces perihemorrhagic edema after intracerebral hemorrhage. Stroke 2010; 41: 1684-9.

https://doi.org/10.1161/STROKEAHA.110.587758

21. Hemphill JC, Bonovich DC, Besmertis L, et al. A Simple, Reliable Grading Scale for Intracerebral Hemorrhage. Stroke 2001;32:891-7. https://doi.org/10.1161/01.STR.32.4.891

22. Palm F, Henschke N, Wolf J, et al. Intracerebral haemorrhage in a population-based stroke registry (LuSSt): incidence, aetiology, functional outcome and mortality. J Neurol 2013; 260 (10): 2541-50. https://doi.org/10.1007/s00415-013-7013-0 


\title{
Povezanost parametara sa prijema na bolničko lečenje i stepena funkcionalnog oporavka kod terapijski konzervativno lečenih pacijenata sa spontanim moždanim krvarenjem
}

\author{
Srđan Ljubisavljević1,2, Aleksandra Ignjatović1,3 \\ ${ }^{1}$ Univerzitet u Nišu, Medicinski fakultet, Niš, Srbija \\ ${ }^{2}$ Klinika za neurologiju, Klinički centar Niš, Niš, Srbija \\ ${ }^{3}$ Institut za javno zdravlje Niš, Niš, Srbija
}

\section{SAŽETAK}

Cilj rada bio je ispitati povezanost parametara sa prijema na bolničko lečenje i kliničkog ishoda kod pacijenata sa netraumatskim intracerebralnim krvarenjem (ICK) mlađih od 65 godina, koji su terapijski konzervativno tretirani.

Analizirani podaci prikupljeni su iz medicinske dokumentacije 341 pacijenta sa ICK. Analizirani su demografski, klinički, radiološki, biohemijski i drugi relevantni parametri sa prijema na bolničko lečenje u odnosu na funkcionalni ishod ICK prilikom otpusta sa bolničkog lečenja.

Sledeći parametri prepoznati su kao prediktori fatalnog kliničkog ishoda: niže vrednosti GCS (OR 0,686; p $=0,023$ ), visoke vrednosti NIHSS (OR 1,258; $p<0,001$ ), povišena telesna temperatura (OR 1,896; $p=0,034$ ), odsustvo glavobolje $u$ kliničkoj prezentaciji ICK (OR 0,298; $p=0,012)$ i ubrzana sedimentacija u prvom satu (OR 1,028; $p=$ 0,045). Prediktori dobrog kliničkog ishoda nakon ICK bili su: visoke vrednosti GCS (OR 1,876; $p=0,032)$, niže vrednosti NIHSS (OR 0,841; $p=0,002)$ i postojanje glavobolje $u$ kliničkoj prezentaciji ICK (OR 5,115; $p=0,001)$.

Poznavanje faktora predikcije kliničkog ishoda nakon ICK značajno je za prepoznavanje pacijenata sa visokim rizikom za progresiju ICK i loš klinički ishod. Ovo može biti korisno u izboru patogenetske terapije koja bi progresiju ICK mogla prevenirati.

Ključne reči: moždano krvarenje, funkcionalni oporavak 